\title{
Lipophilic Extractives from the Cortex and Pith of Elephant Grass (Pennisetum purpureum Schumach.) Stems
}

\author{
Pepijn Prinsen, Ana Gutiérrez, and José C. del Río* \\ Instituto de Recursos Naturales y Agrobiología de Sevilla, CSIC, P.O. Box 1052, E-41080 Seville, Spain
}

ABSTRACT: The composition of lipophilic extractives in the cortex and pith of elephant grass (Pennisetum purpureum Schumach.) stems was thoroughly studied by gas chromatography-mass spectrometry. The predominant compounds were fatty acids followed by sterols (in free and conjugated forms as esters and glycosides). Other steroid compounds, as steroid hydrocarbons and ketones, were also present. Additionally, important amounts of mono-, di-, and triglycerides were identified. Other aliphatic series such as $n$-alkanes, $n$-fatty alcohols, and $n$-alkyl ferulates, together with tocopherols and a series of high molecular weight esters, were also found, although in minor amounts. The analyses also revealed the presence of a $\beta$-diketone (12,14-tritriacontanedione), which was particularly abundant in the cortex. Finally, two lignans, matairesinol and syringaresinol, were also detected. In general terms, the abundances of the different classes of compounds were higher in the pith, except for the series of $n$-fatty alcohols, $n$-alkyl ferulates, $\beta$-diketones, and lignans, which were more prominent in the cortex.

KEYWORDS: elephant grass, Pennisetum purpureum, lipids, fatty acids, sterols, $\beta$-diketones, lignans

\section{INTRODUCTION}

Elephant grass (Pennisetum purpureum Schumach.), also called Napier grass, is a species from the Poaceae (alt. Gramineae), native to the tropical grasslands of Africa and now introduced into most tropical and subtropical countries. It should not be confused with the species Miscanthus $\times$ giganteus, which is also sometimes called elephant grass. The species is a robust grass with perennial stems, reaching over $3 \mathrm{~m}$ high, and is widely recognized as having the highest biomass productivity among herbaceous plants, attaining up to $45 \mathrm{t}$ per ha per year. Elephant grass is therefore considered to be an excellent feedstock to provide abundant and sustainable resources of lignocellulosic biomass for the production of energy, industrial chemicals, and/or pulp and paper. ${ }^{2,3}$ Detailed studies on the chemical composition of elephant grass are important for optimizing the industrial use of this raw material. Hence, some preliminary studies on Napier grass fibers have been reported in the literature, 4,5 although a complete and thorough characterization of the chemical composition of this crop has not been performed so far. A previous paper from our group has already described in detail the characteristic of the lignin polymer of elephant grass; $^{6}$ however, to our knowledge, no previous studies have been published dealing with the composition of the lipophilic extractives in this species. Previous papers have, however, described the lipophilic extractives in related species from the Poaceae, $M . \times$ giganteus $^{7}$ and Arundo donax. ${ }^{8}$

Extractives are a heterogeneous group of compounds dissolving in organic solvents (such as acetone or dichloromethane). Lipophilic extractives from lignocellulosic materials are composed mainly of fatty and resin acids, fatty acid esters (e.g., steryl esters, waxes, triglycerides), and neutral compounds such as fatty alcohols, sterols, and sterol glycosides. ${ }^{9}$ The amount and composition of extractives vary markedly with the plant species. Plant extractives present a special relevance, because the low degradability of most of these compounds causes problems during the industrial processing of lignocellu- losic materials, that is, pitch deposition during paper pulp manufacturing. ${ }^{9-14}$ On the other hand, in the so-called biorefinery concept, all organic fractions derived from lignocellulosic materials can potentially be used, including the lipophilic fractions, which can be also a highly valuable source of phytochemicals. ${ }^{7}$

In this paper, we have carried out a thorough analytical study of the composition of the lipophilic fraction of elephant grass, which has not yet been addressed. For this purpose, the elephant grass stems were separated into the cortex and the pith, and these two fractions were analyzed independently. The analyses were carried out by gas chromatography (GC) and gas chromatography-mass spectrometry (GC-MS) using shortand medium-length high-temperature capillary columns, respectively, with thin films, according to the method previously described that enables the elution and analysis of a wide range of compounds, from fatty acids to intact high molecular weight lipids. ${ }^{15}$ The detailed identification of the lipophilic components of elephant grass is therefore an important step in the search for new solutions to control pitch deposition as well as to evaluate their potential use as a source of high added value phytochemicals.

\section{MATERIALS AND METHODS}

Samples. Elephant grass (P. purpureum Schumach.), cultivar 'Paraiso', was supplied by the University of Viçosa (Brazil). Elephant grass stems were air-dried and subsequently separated into the cortex and the pith. The dried cortex and pith samples were milled using a knife mill (Janke and Kunkel, Analysenmühle) and subsequently extracted with acetone in a Soxhlet apparatus for $8 \mathrm{~h}$. The acetone extracts were evaporated to dryness and redissolved in chloroform for

Received: April 23, 2012

Revised: $\quad$ May 28, 2012

Accepted: May 31, 2012

Published: May 31, 2012 

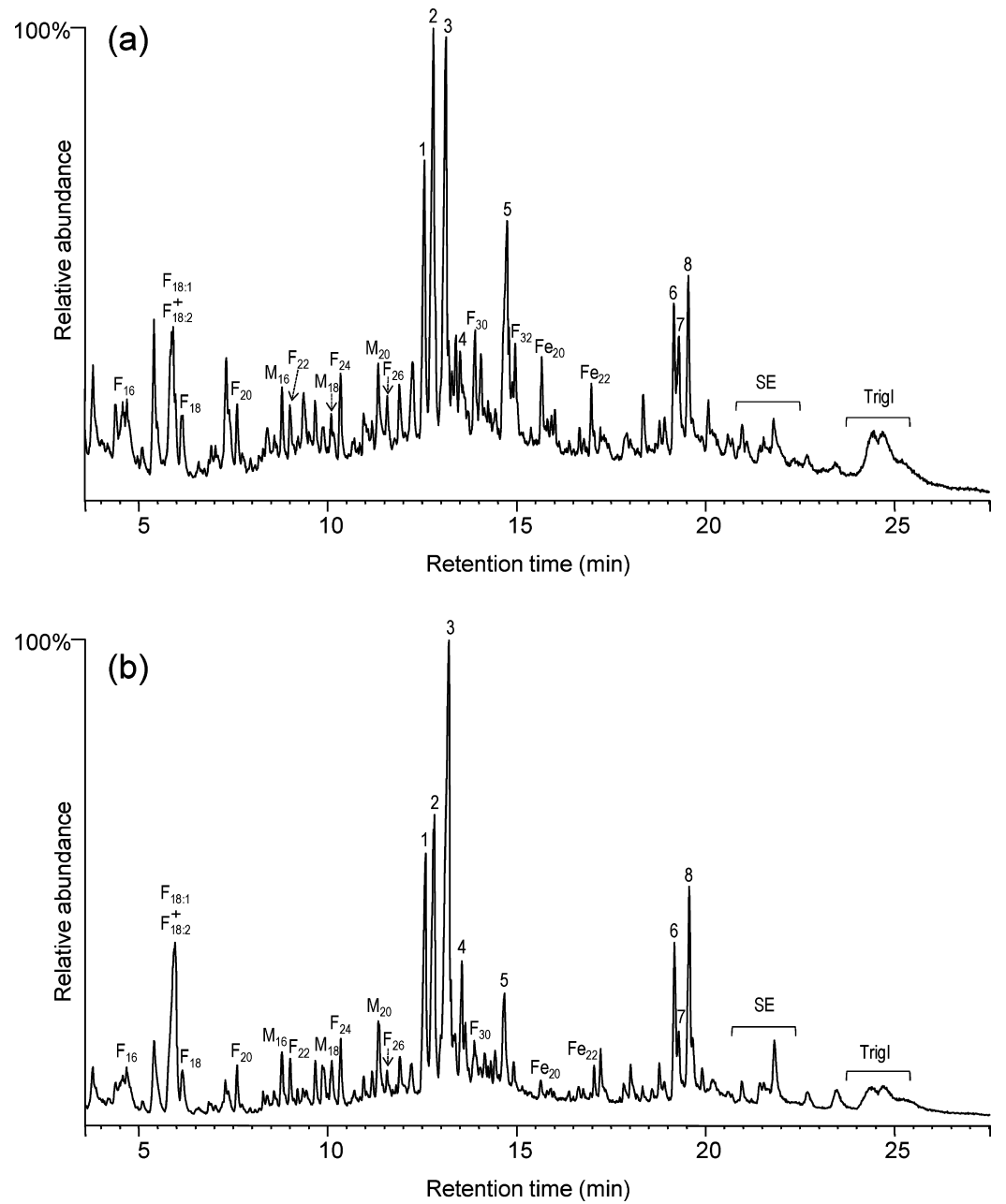

Figure 1. GC-MS chromatograms of the TMS ether derivatives of the lipid extracts from (a) the cortex and (b) the pith of elephant grass (P. purpureum Schumach.) stems. $\mathrm{F}(n), n$-fatty acids; $\mathrm{M}(n)$, monoglycerides; $\mathrm{Fe}(n)$ : trans- $n$-alkyl ferulates ( $n$ indicates the carbon atom number); SE, sterol esters; Trigl, triglycerides. Other compounds reflected in the chromatograms are (1) campesterol; (2) stigmasterol; (3) sitosterol; (4) stigmasta-4-en-3-one; (5) 12,14-tritriacontanone; (6) campesteryl 3 $\beta$-D-glucopyranoside; (7) stigmasteryl 3 $\beta$-D-glucopyranoside; (8) sitosteryl $3 \beta$-Dglucopyranoside.

chromatographic analysis of the lipophilic fraction. Duplicates were used for each sample.

GC and GC-MS Analyses. An HP 5890 gas chromatograph (Hewlett-Packard, Hoofddorp, The Netherlands) equipped with a split-splitless injector and a flame ionization detector (FID) was used for GC analyses. The injector and detector temperatures were set at 300 and $350{ }^{\circ} \mathrm{C}$, respectively. Samples were injected in the splitless mode. Helium was used as the carrier gas. The capillary column used was a high-temperature, polyimide-coated fused silica tubing DB5-HT ( $5 \mathrm{~m} \times 0.25 \mathrm{~mm}$ i.d., $0.1 \mu \mathrm{m}$ film thickness; J\&W Scientific). The oven was temperature-programmed from $100{ }^{\circ} \mathrm{C}$ (held for $1 \mathrm{~min}$ ) to $350{ }^{\circ} \mathrm{C}$ (held for $3 \mathrm{~min}$ ) at $15{ }^{\circ} \mathrm{C} \mathrm{min}^{-1}$. Peaks were quantified by area, and a mixture of standards (tetradecane, palmitic acid, cholest-4-en-3-one, sitosterol, cholesteryl stearate, sitosteryl $3 \beta$-D-glucopyranoside, and glyceroltriheptadecanoate) was used to elaborate calibration curves. The data from the two replicates were averaged. In all cases, the standard deviations from replicates were below $10 \%$ of the mean values.

The GC-MS analyses were performed on a Varian Star 3400 gas chromatograph (Varian, Walnut Creek, CA, USA) coupled with an ion-trap detector (Varian Saturn) equipped with a high-temperature capillary column (DB-5HT, $15 \mathrm{~m} \times 0.25 \mathrm{~mm}$ i.d., $0.1 \mu \mathrm{m}$ film thickness; J\&W Scientific). Helium was used as carrier gas at a rate of $2 \mathrm{~mL} / \mathrm{min}$. The oven was heated from $120^{\circ} \mathrm{C}$ (held for $1 \mathrm{~min}$ ) to $380{ }^{\circ} \mathrm{C}$ (held for $5 \mathrm{~min}$ ) at $10{ }^{\circ} \mathrm{C} \mathrm{min}^{-1}$. The temperature of the injector during the injection was $120{ }^{\circ} \mathrm{C}$ and $0.1 \mathrm{~min}$ after injection was programmed to $380{ }^{\circ} \mathrm{C}$ at a rate of $200{ }^{\circ} \mathrm{C} \mathrm{min}-1$ and held for $10 \mathrm{~min}$. The temperature of the transfer line was set at $300{ }^{\circ} \mathrm{C}$. Bis(trimethylsilyl)trifluoroacetamide (BSTFA) silylation was used when required to form the TMS ether derivatives. Compounds were identified by comparing their mass spectra with mass spectra in the Wiley and NIST libraries, by mass fragmentography, and, when possible, by comparison with authentic standards.

\section{RESULTS AND DISCUSSION}

The elephant grass stem consisted of two differentiated parts, a cortex and a pith, that accounted for 84 and $16 \%(w / w)$ of the whole stem, respectively. The chemical composition of the lipophilic extractives was studied separately in both parts of the stem. The abundance of the main constituents (water-solubles, acetone extractives, Klason lignin, acid soluble lignin, holocellulose, $\alpha$-cellulose, and ash) in the cortex and pith of elephant grass stem has been detailed in a previous paper. ${ }^{6}$ The total acetone extractives in the cortex and pith of elephant grass account for 1.7 and $2.3 \%$ of dry material, respectively. However, the lipophilic content, estimated as the chloroform-soluble fraction, is lower and accounts for only 0.8 and $1.6 \%$, respectively. This content is similar to that found in the related species from the Poaceae giant reed, ${ }^{8}$ and $M . \times$ giganteus. $^{7}$ Interestingly, in $M . \times$ giganteus, a higher abundance of lipophilic 
Table 1. Composition and Abundance of the Main Lipophilic Compounds Identified in the Extracts of the Cortex and Pith of Elephant Grass (P. purpureum Schumach.) Stems

\begin{tabular}{|c|c|c|c|c|c|}
\hline compound & $\begin{array}{c}\text { cortex } \\
(\mathrm{mg} / \mathrm{kg}, \mathrm{daf})\end{array}$ & $\begin{array}{c}\text { pith } \\
\text { (mg/kg, daf) }\end{array}$ & compound & $\begin{array}{c}\text { cortex } \\
(\mathrm{mg} / \mathrm{kg}, \mathrm{daf})\end{array}$ & $\begin{array}{c}\text { pith } \\
(\mathrm{mg} / \mathrm{kg} \text {, daf) }\end{array}$ \\
\hline$n$-fatty acids & 991 & 1497 & 2,3-dihydroxypropyl octadecadienoate & 21 & 60 \\
\hline$n$-tetradecanoic acid & 18 & 35 & 2,3-dihydroxypropyl octadecenoate & 6 & 19 \\
\hline$n$-pentadecanoic acid & 10 & 20 & 2,3-dihydroxypropyl octadecanoate & 15 & 21 \\
\hline$n$-hexadecanoic acid & 176 & 231 & 2,3-dihydroxypropyl eicosanoate & 15 & 23 \\
\hline$n$-heptadecanoic acid & 19 & 20 & 2,3-dihydroxypropyl docosanoate & 11 & 32 \\
\hline n-octadeca-9,12-dienoic acid & 196 & 514 & 2,3-dihydroxypropyl tricosanoate & 3 & 20 \\
\hline n-octadec-9-enoic acid & 61 & 116 & 2,3-dihydroxypropyl tetracosanoate & 13 & 48 \\
\hline$n$-octadecanoic acid & 89 & 100 & 2,3-dihydroxypropyl pentacosanoate & 3 & 7 \\
\hline$n$-nonadecanoic acid & 12 & 17 & 2,3-dihydroxypropyl hexacosanoate & 5 & 8 \\
\hline$n$-eicosanoic acid & 50 & 70 & 2,3-dihydroxypropyl heptacosanoate & 1 & 1 \\
\hline $\begin{array}{l}n \text {-heneicosanoic acid } \\
n \text {-docosanoic acid }\end{array}$ & $\begin{array}{l}10 \\
43\end{array}$ & $\begin{array}{l}26 \\
68\end{array}$ & 2,3-dihydroxypropyl octacosanoate & 2 & 2 \\
\hline $\begin{array}{l}n \text {-docosanoic acid } \\
n \text {-tricosanoic acid }\end{array}$ & $\begin{array}{l}43 \\
25\end{array}$ & 40 & 2,3-dihydroxypropyl triacontanoate & 3 & 0 \\
\hline$n$-tetracosanoic acid & 61 & 88 & & & \\
\hline$n$-pentacosanoic acid & 25 & 31 & diglycerides & 50 & 179 \\
\hline$n$-hexacosanoic acid & 35 & 25 & 1,2-dipalmitin & 4 & 1 \\
\hline$n$-heptacosanoic acid & 5 & 2 & 1,3-dipalmitin & 8 & 11 \\
\hline n-octacosanoic acid & 40 & 15 & 1,2-palmitoyllinolein & 4 & 30 \\
\hline$n$-nonacosanoic acid & 4 & 9 & 1,2-palmitoylolein & 4 & 10 \\
\hline$n$-triacontanoic acid & 58 & 35 & 1,2-palmitoylstearin & 3 & 2 \\
\hline$n$-hentriacontanoic acid & 5 & 3 & 1,3-palmitoyllinolein & 6 & 43 \\
\hline$n$-docotriacontanoic acid & 38 & 27 & 1,3-palmitoylolein & 5 & 17 \\
\hline$n$-tritriacontanoic acid & 2 & 1 & 1,3-palmitoylstearin & 11 & 9 \\
\hline$n$-tetratriacontanoic acid & 9 & 4 & 1,2-dilinolein & 1 & 22 \\
\hline & & & 1,3-dilinolein & 2 & 21 \\
\hline$n$-fatty alcohols & 14 & 4 & 1,2-distearin & 0 & 5 \\
\hline $\begin{array}{l}n \text {-tetracosanol } \\
n \text {-hexacosanol }\end{array}$ & $\begin{array}{l}1 \\
4\end{array}$ & $\begin{array}{l}1 \\
1\end{array}$ & 1,3-distearin & 2 & 8 \\
\hline$n$-octacosanol & 9 & 2 & triglycerides & 26 & 135 \\
\hline$n$-alkanes & 14 & 21 & dipalmitoyllinolein & 6 & 30 \\
\hline$n$-tricosane & 1 & 1 & palmitoyldilinolein & 13 & 69 \\
\hline$n$-tetracosane & 0 & $\operatorname{tr}$ & trilinolein & 7 & 36 \\
\hline$n$-pentacosane & 2 & 3 & & & \\
\hline$n$-hexacosane & $\operatorname{tr}$ & $\operatorname{tr}$ & steroid hydrocarbons & 10 & 21 \\
\hline$n$-heptacosane & 1 & 2 & ergosta-3,5-diene & 4 & 8 \\
\hline$n$-octacosane & $\operatorname{tr}$ & $\operatorname{tr}$ & stigmasta-3,5,7-triene & 2 & 4 \\
\hline$n$-nonacosane & 5 & 7 & stigmasta-3,5-diene & 4 & 9 \\
\hline$n$-triacontane & $\operatorname{tr}$ & 1 & & & \\
\hline$n$-hentriacontane & 4 & 6 & steroid ketones & 89 & 381 \\
\hline$n$-dotriacontane & \multirow{2}{*}{1} & \multirow{2}{*}{$\operatorname{tr}$} & ergost-4-en-3-one & 10 & 33 \\
\hline$n$-tritriacontane & & & stigmasta-4,22-dien-3-one & 17 & 47 \\
\hline \multirow[b]{2}{*}{ tocopherols } & \multirow[b]{2}{*}{10} & \multirow[b]{2}{*}{9} & stigmasta-3,5-dien-7-one & 2 & 9 \\
\hline & & & stigmast-4-en-3-one & 25 & 117 \\
\hline \multirow{2}{*}{$\beta$-tocopherol } & \multirow{2}{*}{$\begin{array}{l}5 \\
5\end{array}$} & \multirow{2}{*}{$\begin{array}{l}5 \\
4\end{array}$} & ergost-4-ene-3,6-dione & 4 & 22 \\
\hline & & & ergostane-3,6-dione & 4 & 15 \\
\hline$n$-alkyl ferulates & 23 & 10 & stigmasta-4,22-diene-3,6-dione & 8 & 22 \\
\hline trans-eicosanylferulate & 13 & 7 & stigmast-22-ene-3,6-dione & 5 & 17 \\
\hline \multirow{2}{*}{$\begin{array}{l}\text { trans-elcosanylferulate } \\
\text { trans-docosanylferulate }\end{array}$} & \multirow{2}{*}{$\begin{array}{l}13 \\
10\end{array}$} & \multirow{2}{*}{$\begin{array}{l}7 \\
3\end{array}$} & stigmast-4-ene-3,6-dione & 7 & 64 \\
\hline & & & stigmastane-3,6-dione & 7 & 35 \\
\hline high molecular weight esters ${ }^{a}$ & 62 & 88 & & & \\
\hline esters $\mathrm{C}_{38}$ & 2 & 4 & sterols & 327 & 1096 \\
\hline esters $\mathrm{C}_{40}$ & 13 & 49 & campesterol & 74 & 198 \\
\hline esters $\mathrm{C}_{42}$ & 11 & 8 & stigmasterol & 113 & 291 \\
\hline esters $\mathrm{C}_{44}$ & 17 & 15 & sitosterol & 139 & 585 \\
\hline esters $\mathrm{C}_{46}$ & 16 & 8 & 7-oxositosterol & 1 & 22 \\
\hline \multirow[t]{2}{*}{ etsres $\mathrm{C}_{48}$} & 3 & 4 & & & \\
\hline & & & sterol glycosides & 121 & 435 \\
\hline monoglycerides & 150 & 343 & campesteryl- $\beta$-D-glucopyranoside & 50 & 147 \\
\hline 2,3-dihydroxypropyl tetradecanoate & 2 & 2 & stigmasteryl- $\beta$-D-glucopyranoside & 34 & 49 \\
\hline 2,3-dihydroxypropyl hexadecanoate & 50 & 98 & sitosteryl- $\beta$-D-glucopyranoside & 67 & 239 \\
\hline
\end{tabular}


Table 1. continued

compound

$\begin{array}{cc}\text { cortex } & \text { pith } \\ (\mathrm{mg} / \mathrm{kg}, \mathrm{daf}) & (\mathrm{mg} / \mathrm{kg}, \mathrm{daf})\end{array}$

sterol esters

campesteryl esters

stigmasteryl esters

sitosteryl esters

\section{$\boldsymbol{\beta}$-diketones}

12,14-tritriacontanedione

$\begin{array}{rr}\mathbf{5 4} & \mathbf{1 8 1} \\ 11 & 33 \\ 11 & 26 \\ 32 & 122 \\ & \\ 156 & \mathbf{7 5} \\ 156 & 75\end{array}$

compound

cortex

(mg/kg, daf)

pith

(mg/kg, daf)

\section{lignans}

matairesinol

syringaresinol

$\begin{array}{ll}9 & 0 \\ 3 & 0 \\ 6 & 0\end{array}$

${ }^{a}$ See Table 2 for the identification and quantitation of the individual high molecular weight esters.<smiles>CCCCCCCCCCCCCCC(C)O</smiles>

(I)<smiles>CCCCCCCCC=CCCCCCCCC(=O)O</smiles>

(II)

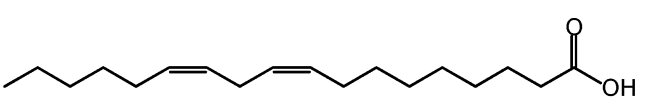

(III)<smiles>CCCCCCCCCCCCCCCCCCCCCCCCCCCO</smiles>

(IV)

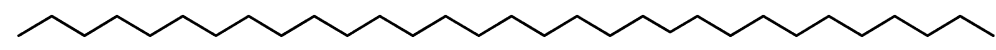

(V)<smiles>CCCCCCCCCCCCCCCCCCCCOC(=O)/C=C/c1ccc(O)c(OC)c1</smiles><smiles>CCCCCCC=CCCCCCCCCCCC(=O)OCC(CO)OC(=O)CCCCCCCCCCCCCC</smiles><smiles>CCCCCCCCC=CCCCCCCCCC(=O)C(O)CC(O)COC(=O)CCCCCCCCCCCCCCC</smiles>

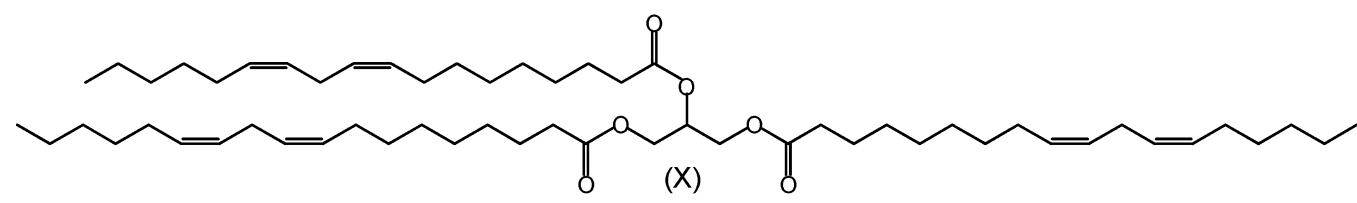<smiles>CCCCCCCCCCCCCCCCCCCCC(O)CC(=O)CCCCCCCCCCCCCCCCCCCCCCCCC(O)C(=O)CCCCCCCCCCCCCCCCCCC</smiles>

(XII)

Figure 2. Structures of compounds representative of the main aliphatic series identified among the lipophilic extractives in elephant grass (P. purpureum Schumach.) and referred to in the text. (I) $n$-hexadecanoic (palmitic) acid; (II) 9-octadecenoic (oleic) acid; (III) 9,12-octadecadienoic (linoleic) acid; (IV) n-octacosanol; (V) n-hentriacontane; (VI) trans-eicosyl ferulate; (VII) 2,3-dihydroxypropyl hexadecanoate (1-monopalmitin); (VIII) 1,2-palmitoyllinolein; (IX) 1,3-palmitoyllinolein; (X) trilinolein; (XI) eicosanoic acid, eicosyl ester; (XII) 12,14-tritriacontanedione. 
<smiles>CCC(C)C(C)CCC(C)C1CCC2C3CC[C@H]4CC(O)CCC4(C)C3CCC12C</smiles>

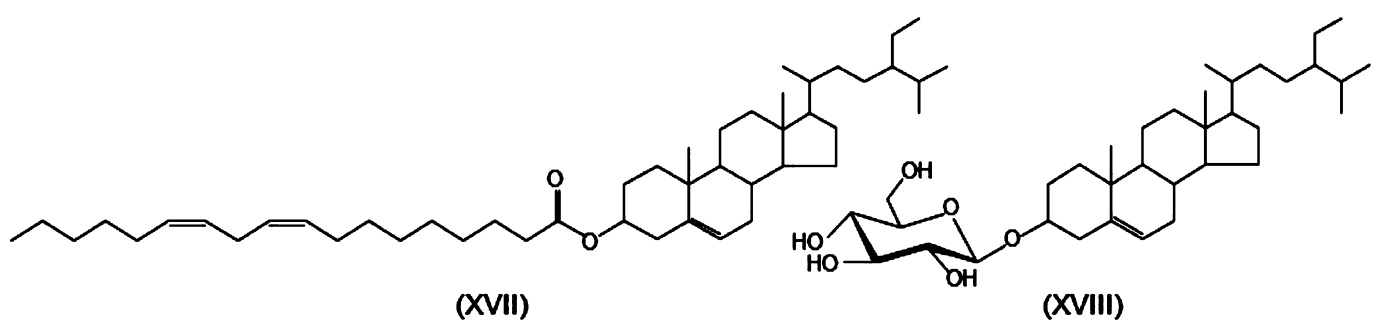

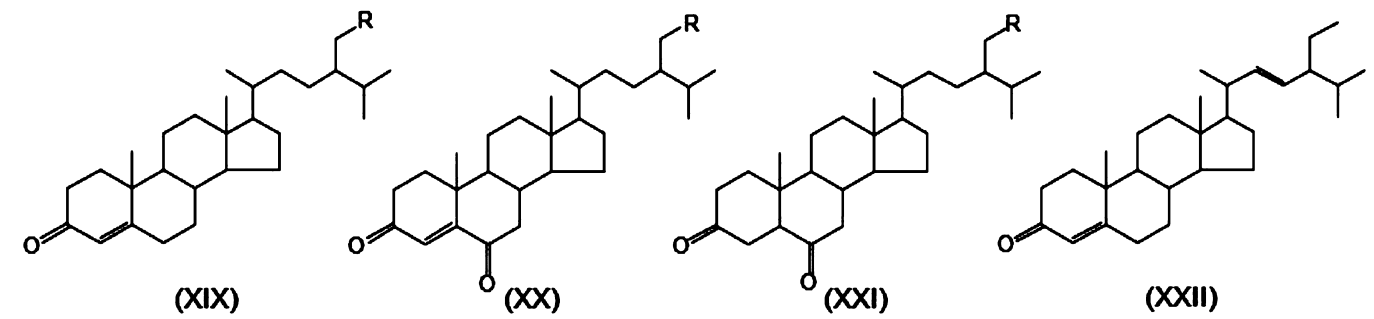

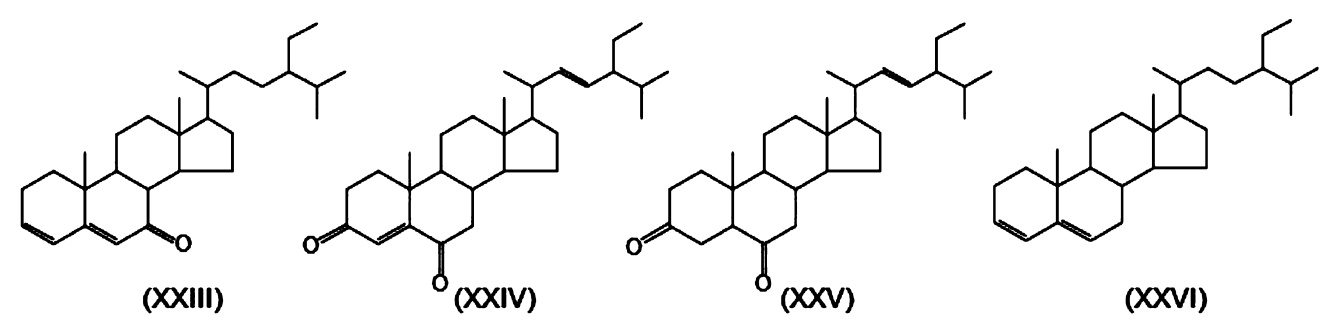

Figure 3. Structures of the main steroid compounds identified among the lipophilic extractives in elephant grass (P. purpureum Schumach.) and referred to in the text. (XIII) sitosterol; (XIV) campesterol; (XV) stigmasterol; (XVI) 7-oxositosterol; (XVII) sitosteryl linoleate; (XVIII) sitosteryl $3 \beta$-D-glucopyranoside; $(\mathrm{XIX})$ ergost-4-en-3-one $(\mathrm{R}=\mathrm{H})$, stigmast-4-en-3-one $\left(\mathrm{R}=\mathrm{CH}_{3}\right) ;(\mathrm{XX})$ ergost-4-ene-3,6-dione $(\mathrm{R}=\mathrm{H})$, stigmast-4-ene-3,6dione; (XXI) ergostane-3,6-dione $(\mathrm{R}=\mathrm{H})$, stigmastane-3,6-dione $\left(\mathrm{R}=\mathrm{CH}_{3}\right)$; (XXII) stigmasta-4,22-dien-3-one; (XXIII) stigmasta-3,5-dien-7-one; (XXIV) stigmasta-4,22-diene-3,6-dione; (XXV) stigmast-22-ene-3,6-dione; (XXVI) stigmasta-3,5-diene.

extractives was also found in the pith compared with the cortex. ${ }^{7}$ The content is also similar to that found in other nonwoody fibers, such as flax, ${ }^{16,17}$ hemp, ${ }^{18}$ kenaf, $^{19}$ sisal, $^{20}$ abaca, ${ }^{21}$ or jute. ${ }^{22}$

The composition of the lipophilic extracts in the cortex and pith of elephant grass was analyzed in detail by GC and GC-MS according to previously developed protocols. ${ }^{15}$ The GC-MS chromatograms of the TMS ether derivatives of the extracts from the cortex and pith of elephant grass are shown in Figure 1. The identities and abundances of the main compounds identified are detailed in Table 1.

The predominant lipophilic compounds in the cortex and pith of elephant grass were a series of free fatty acids that accounted for nearly $50 \%$ of all identified compounds in the cortex and up to $33 \%$ of the compounds in the pith. Sterols (in free and conjugated forms as esters and glycosides) were also prominent and accounted for $25 \%$ of all compounds in the cortex and $38 \%$ of the compounds in the pith. Other steroid compounds present were steroid hydrocarbons and ketones. Additionally, significant amounts of glycerides (mono-, di-, and triglycerides) and a $\beta$-diketone were also identified among the extracts. Other aliphatic series such as $n$-alkanes, $n$-fatty alcohols, $n$-alkyl ferulates, and high molecular weight wax esters, together with tocopherols, occurred in minor amounts. The structures of the main classes of lipophilic compounds identified in the cortex and pith of elephant grass are depicted in Figures 2 and 3, and the distributions of the main aliphatic series are represented in the histograms of Figure 4. In general terms, the abundances of the different classes of lipophilic compounds were higher in the pith than in the cortex, as also observed in the related species $M . \times$ giganteus, ${ }^{7}$ except for the series of $n$-fatty alcohols, $n$-alkyl ferulates, $\beta$-diketones, and lignans, which were more abundant in the cortex.

Aliphatic Series. As said above, the most important class of lipophilic compounds observed in the cortex and pith of elephant grass comprised free fatty acids, which accounted for $991 \mathrm{mg} / \mathrm{kg}$ in the cortex and $1497 \mathrm{mg} / \mathrm{kg}$ in the pith. Free fatty acids were identified in the range from tetradecanoic $\left(\mathrm{C}_{14}\right)$ to tetratriacontanoic $\left(\mathrm{C}_{34}\right)$ acid, with a strong even-over-odd carbon atom predominance, hexadecanoic acid (palmitic acid, I) being the most abundant saturated fatty acid. The unsaturated 9-octadecenoic (oleic acid, II) and 9,12-octadecadienoic 

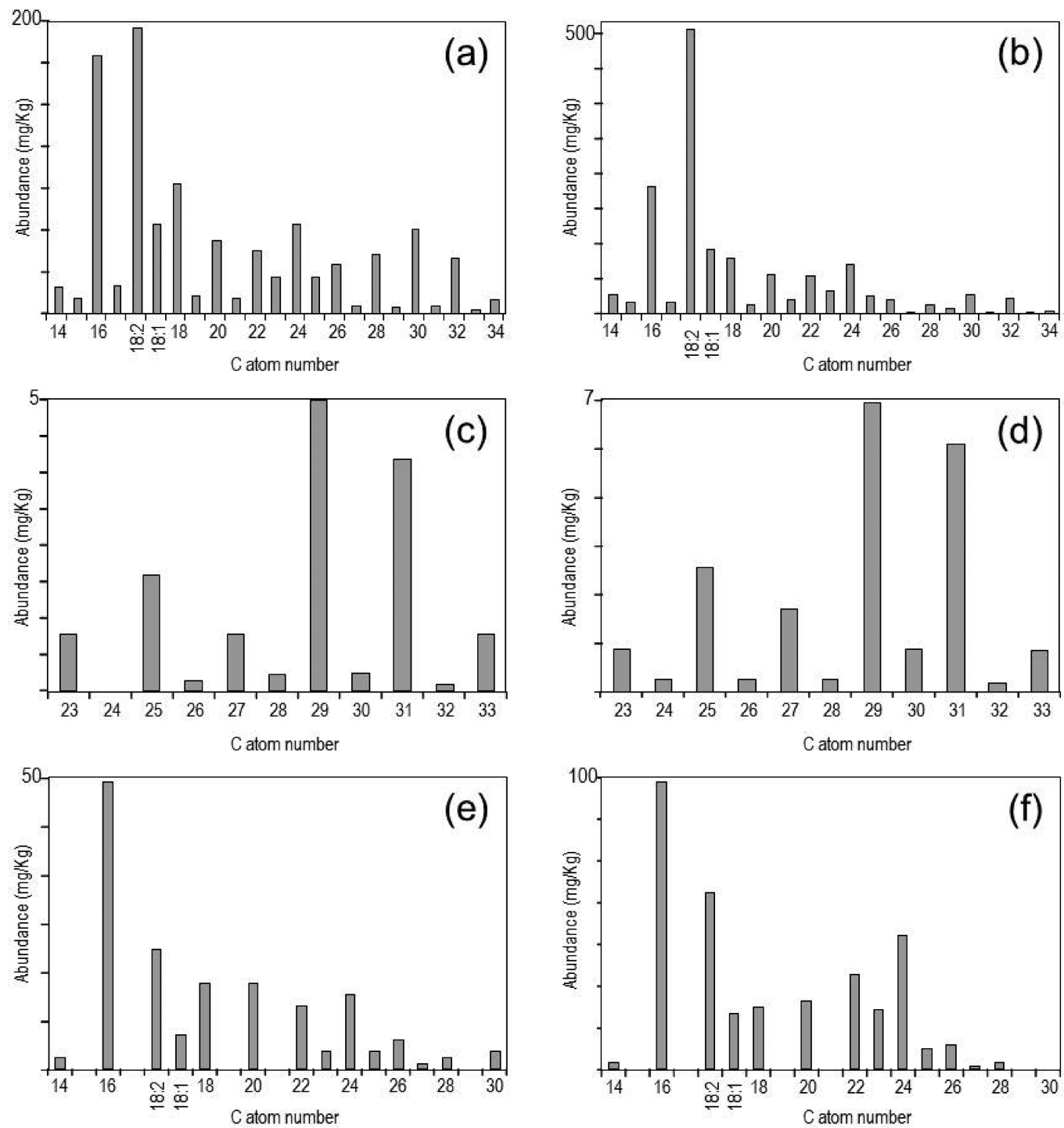

Figure 4. Distribution of the main aliphatic series identified in the extracts of elephant grass (P. purpureum Schumach.): series of $n$-fatty acids in the cortex (a) and in the pith (b); series of $n$-alkanes in the cortex (c) and in the pith (d); series of monoglycerides in the cortex (e) and in the pith (f). The histograms are scaled up to the abundance of the major compound in the series.

(linoleic acid, III) acids were also present, the latter being the most abundant free fatty acid in both the cortex and pith. A series of $n$-fatty alcohols ranging from tetracosanol $\left(\mathrm{C}_{24}\right)$ to octacosanol $\left(\mathrm{C}_{28}\right)$ were present in elephant grass extracts, albeit in low amounts $(14 \mathrm{mg} / \mathrm{kg}$ in the cortex and $4 \mathrm{mg} / \mathrm{kg}$ in the pith) with the presence of only the even carbon atom number, octacosanol (IV) being the most abundant. Fatty alcohols also occurred in higher amounts in the cortex than in the pith in the related species $M . \times$ giganteus. $^{7}$ A series of $n$-alkanes ranging from tricosane $\left(\mathrm{C}_{23}\right)$ to tritriacontane $\left(\mathrm{C}_{33}\right)$ also occurred in elephant grass in low amounts $(14 \mathrm{mg} / \mathrm{kg}$ in the cortex and $21 \mathrm{mg} / \mathrm{kg}$ in the pith) with a strong odd-over-even carbon atom number predominance, nonacosane (V) being the most abundant followed by hentriacontane.

A series of ferulic acid esterified to long-chain fatty alcohols were also identified among the extracts of elephant grass and accounted for $25 \mathrm{mg} / \mathrm{kg}$ in the cortex and $10 \mathrm{mg} / \mathrm{kg}$ in the pith. Their characterization was achieved on the basis of the mass spectra obtained by GC-MS of the underivatized and their TMS ether derivatives. ${ }^{23}$ The series of $n$-alkyl ferulates occurred in the range from $\mathrm{C}_{20}$ to $\mathrm{C}_{22}$, with the presence of only the even carbon atom number homologues, trans-eicosylferulate (VI) being the most abundant. This series of $n$-alkyl ferulates occurred mostly in the trans form, although minor amounts of the cis isomers were also observed at lower retention times. Alkyl ferulates have been widely reported in different plant families, ${ }^{20,21,23-26}$ although they were not found in the related species giant reed $^{8}$ and $M . \times$ giganteus. $^{7}$

Glycerides (mono-, di-, and triglycerides) were another class of compounds present in significant amounts in the cortex and pith of elephant grass. Glycerides, and especially mono- and diglycerides, were reported in the related species from the Poacea giant reed $^{8}$ but were not reported among the lipophilic extractives in $M . \times$ giganteus, ${ }^{7}$ despite the fact that mono- and diglycerides are very common constituents in many plants. $^{21,27,28}$ Monoglycerides were the most abundant glycerides in elephant grass, with $150 \mathrm{mg} / \mathrm{kg}$ in the cortex and $343 \mathrm{mg} / \mathrm{kg}$ in the pith. The series of monoglycerides were found in the range from $\mathrm{C}_{14}$ to $\mathrm{C}_{30}$, with strong even-overodd carbon atom number predominance, the $\mathrm{C}_{16}$ homologue (1-monopalmitin, VII) being the most abundant, and with the exclusive presence of the isomer in position 1. The unsaturated 
Table 2. Composition and Abundance of the Different Individual High Molecular Weight Esters Identified in the Extracts of the Cortex and Pith of Elephant Grass (P. purpureum Schumach.) Stems

\begin{tabular}{|c|c|c|c|}
\hline compound & $\begin{array}{l}\text { fatty acid/ } \\
\text { fatty alcohol }\end{array}$ & $\begin{array}{l}\text { cortex } \\
(\mathrm{mg} / \mathrm{kg} \\
\text { daf })\end{array}$ & $\begin{array}{c}\text { pith } \\
\text { (mg/kg, } \\
\text { daf) }\end{array}$ \\
\hline esters C38 & & 2 & 4 \\
\hline eicosanoic acid, octadecyl ester & $\mathrm{C}_{20} / \mathrm{C}_{18}$ & 2 & 4 \\
\hline esters C40 & & 13 & 49 \\
\hline hexadecanoic acid, tetracosyl ester & $\mathrm{C}_{16} / \mathrm{C}_{24}$ & 1 & 1 \\
\hline octadec-9-enoic acid, docosyl ester & $\mathrm{C}_{18: 1} / \mathrm{C}_{22}$ & 3 & 8 \\
\hline octadeca-9,12-dienoic acid, docosyl ester & $\mathrm{C}_{18: 2} / \mathrm{C}_{22}$ & 1 & 2 \\
\hline eicosanoic acid, eicosyl ester & $\mathrm{C}_{20} / \mathrm{C}_{20}$ & 6 & 37 \\
\hline docosanoic acid, octadecyl ester & $\mathrm{C}_{22} / \mathrm{C}_{18}$ & 2 & 1 \\
\hline esters $\mathrm{C} 42$ & & 11 & 8 \\
\hline tetradecanoic acid, octacosyl ester & $\mathrm{C}_{14} / \mathrm{C}_{28}$ & 1 & 2 \\
\hline hexadecanoic acid, hexacosyl ester & $\mathrm{C}_{16} / \mathrm{C}_{26}$ & 3 & 2 \\
\hline octadecanoic acid, tetracosyl ester & $\mathrm{C}_{18} / \mathrm{C}_{24}$ & 1 & 1 \\
\hline eicosanoic acid, docosyl ester & $\mathrm{C}_{20} / \mathrm{C}_{22}$ & 1 & 1 \\
\hline docosanoic acid, eicosyl ester & $\mathrm{C}_{22} / \mathrm{C}_{20}$ & 5 & 2 \\
\hline esters C44 & & 17 & 15 \\
\hline hexadecanoic acid, octacosyl ester & $\mathrm{C}_{16} / \mathrm{C}_{28}$ & 12 & 12 \\
\hline octadecanoic acid, hexacosyl ester & $\mathrm{C}_{18} / \mathrm{C}_{26}$ & 3 & 1 \\
\hline eicosanoic acid, tetracosyl ester & $\mathrm{C}_{20} / \mathrm{C}_{24}$ & 1 & 1 \\
\hline docosanoic acid, docosyl ester & $\mathrm{C}_{22} / \mathrm{C}_{22}$ & 1 & 1 \\
\hline esters C46 & & 16 & 8 \\
\hline hexadecanoic acid, triacontyl ester & $\mathrm{C}_{16} / \mathrm{C}_{30}$ & 3 & 2 \\
\hline octadecanoic acid, octacosyl ester & $\mathrm{C}_{18} / \mathrm{C}_{28}$ & 11 & 4 \\
\hline eicosanoic acid, hexacosyl ester & $\mathrm{C}_{20} / \mathrm{C}_{26}$ & 1 & 1 \\
\hline docosanoic acid, tetracosyl ester & $\mathrm{C}_{22} / \mathrm{C}_{24}$ & 1 & 1 \\
\hline esters C48 & & 3 & 4 \\
\hline octadecanoic acid, triacontyl ester & $\mathrm{C}_{18} / \mathrm{C}_{30}$ & 1 & 1 \\
\hline eicosanoic acid, octacosyl ester & $\mathrm{C}_{20} / \mathrm{C}_{28}$ & 1 & 2 \\
\hline docosanoic acid, hexacosyl ester & $\mathrm{C}_{22} / \mathrm{C}_{26}$ & 1 & 1 \\
\hline
\end{tabular}

monoglycerides 1-monoolein and 1-monolinolein were also found in significant amounts. Diglycerides were found in elephant grass in higher abundance in the pith $(179 \mathrm{mg} / \mathrm{kg})$ than in the cortex (50 mg/kg), the most abundant being 1,2-palmitoyllinolein (VIII) and 1,3-palmitoyllinolein (IX). Triglycerides (dipalmitoyllinolein, dilinoleylpalmitin, and trilinolein, $\mathbf{X}$ ) were also present in elephant grass, in contrast to other nonwood fibers such as flax, hemp, and kenaf, which lack triglycerides, ${ }^{16-19}$ and are present in higher abundance in the pith $(135 \mathrm{mg} / \mathrm{kg})$ than in the cortex (26 mg/kg).

A series of high molecular weight wax esters also occurred in elephant grass extract, being more abundant in the pith $(79 \mathrm{mg} / \mathrm{kg})$ than in the cortex $(59 \mathrm{mg} / \mathrm{kg})$. High molecular weight wax esters were found in the range from $\mathrm{C}_{38}$ to $\mathrm{C}_{48}$ with the presence of only the even carbon atom number homologues, the $\mathrm{C}_{44}$ and $\mathrm{C}_{46}$ analogues being the most abundant in the cortex, whereas the homologues $\mathrm{C}_{40}$ were the most abundant in the pith. A close examination of each chromatographic peak indicated that they consisted of different long-chain fatty acids esterified to different long-chain fatty alcohols. The identification and quantitation of the individual long-chain esters in each chromatographic peak were resolved on the baasis of the mass spectra of the peaks. The mass spectra of long-chain esters are characterized by a base peak produced by a rearrangement process involving the transfer of two hydrogen atoms from the alcohol chain to the acid chain, giving a protonated acid ion. ${ }^{29,30}$ Therefore, the base peak gives information about the number of carbon atoms in the acid moiety, whereas the molecular ion provides information about the total number of carbon atoms in the ester. It is possible then to determine the individual contribution of esters to every chromatographic peak by mass spectrometric determination of the molecular ion and the base peak. Quantitation of individual esters was accomplished by integrating the areas in the chromatographic profiles of the ions characteristic for the acidic moiety. The detailed structural composition of the different high molecular weight wax esters identified in elephant grass is shown in Table 2 . The esterified fatty acids ranged from $\mathrm{C}_{14}$ to $\mathrm{C}_{22}$ and the esterified fatty alcohols from $\mathrm{C}_{18}$ to $\mathrm{C}_{30}$. The acyl moiety of the high molecular weight wax esters was exclusively constituted by saturated fatty acids with even carbon number. High molecular weight wax esters with unsaturated fatty acids could be detected only in minor amounts despite the high amounts of oleic and linoleic acids being present in free form. The predominant high molecular weight ester in the cortex of elephant grass was $\mathrm{C}_{44}$, which is mostly constituted by hexadecanoic acid, octacosyl ester, followed by ester $\mathrm{C}_{46}$, mostly constituted by octadecanoic acid, octacosyl ester. In the pith, the predominant high molecular weight ester was $\mathrm{C}_{40}$, mostly constituted by eicosanoic acid, eicosyl ester (XI).

Additionally, two tocopherols, namely, $\alpha$ - and $\beta$-tocopherols, were found among the extracts of the cortex and pith of elephant grass, although in minor amounts, ca. $10 \mathrm{mg} / \mathrm{kg}$.

$\boldsymbol{\beta}$-Diketones. The analysis of the lipophilic extractives of the cortex and pith of elephant grass revealed the presence of significant amounts of a compound with a $\beta$-diketone structure. The identification of this compound was achieved on the basis of its mass spectrum that is depicted in Figure 5. The molecular ion at $m / z 492$ indicates that this is a tritriacontanedienone, and the fragments at $m / z 222$ and 334, arising from the McLafferty rearrangement at both sides of the diketone group followed by loss of water, ${ }^{31}$ clearly indicate that the structure of this compound is 12,14 -tritriacontanedione (XII). $\beta$-Diketones are relatively common constituents of plant waxes and have been identified in the leaves of different grasses. ${ }^{32-36}$ In elephant grass, 12,14-tritriacontanedione was present in higher abundance in the cortex $(156 \mathrm{mg} / \mathrm{kg})$ than in the pith $(75 \mathrm{mg} / \mathrm{kg})$, in contrast to most of the lipophilic compounds.

Steroid Compounds. Different classes of steroid compounds were present in the extracts of the cortex and pith of elephant grass, namely, steroid hydrocarbons, steroid ketones, sterols, sterol glycosides, and sterol esters. Sterols were the most abundant steroid compounds in elephant grass, accounting for $327 \mathrm{mg} / \mathrm{kg}$ in the cortex and $1096 \mathrm{mg} / \mathrm{kg}$ in the pith. The particularly higher abundance of free sterols in the pith was also observed in the related species M. $\times$ giganteus by Villaverde et al., ${ }^{7}$ which indicated this as a potential source of highly valuable sterols. Sitosterol (XIII) was the most important sterol identified in elephant grass extracts, together with campesterol (XIV), stigmasterol (XV), and minor amounts of 7-oxositosterol (XVI). Sterols were also found esterified with long-chain fatty acids and were also more abundant in the pith $(181 \mathrm{mg} / \mathrm{kg})$ than in the cortex $(54 \mathrm{mg} / \mathrm{kg})$. The structures of the sterol esters were determined by their mass spectra. However, sterol esters 


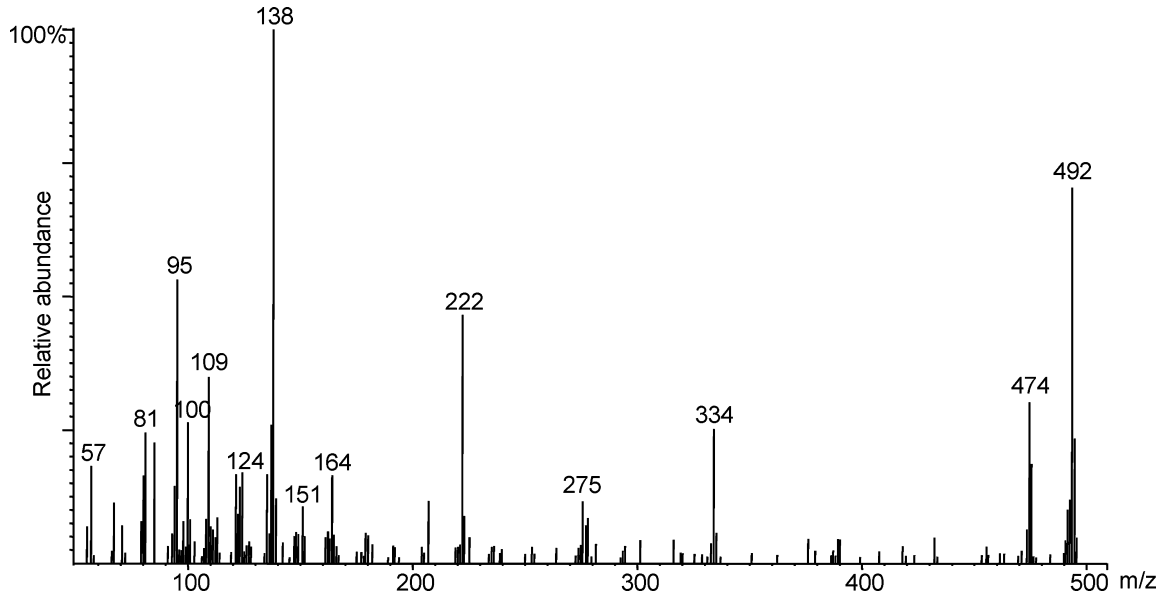

Figure 5. Mass spectrum of 12,14-tritriacontanedione (XII) identified among elephant grass (P. purpureum Schumach.) extracts.
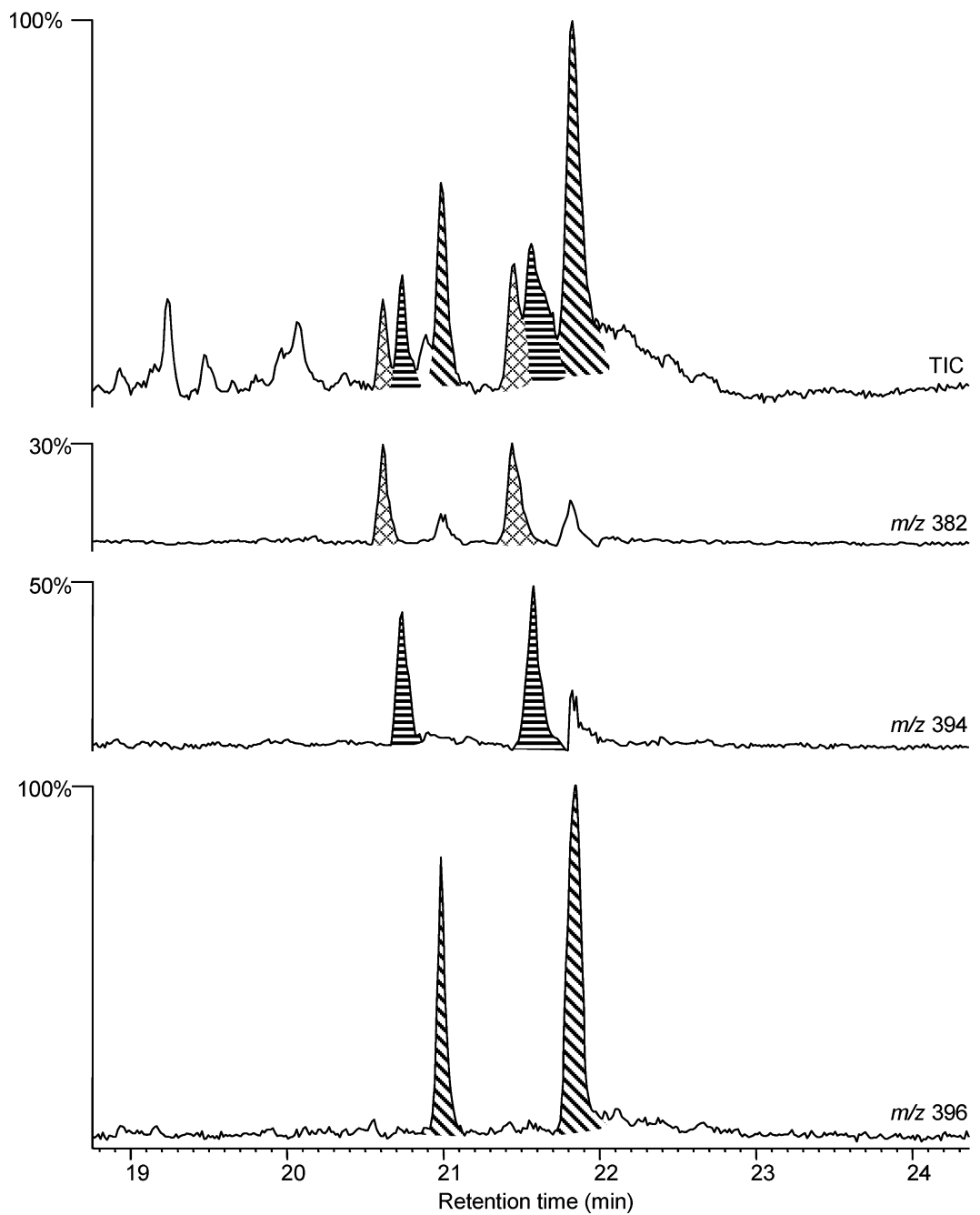

Figure 6. Total ion chromatogram (TIC) and single-ion chromatograms showing the distribution of the different sterol esters in the pith of elephant grass (P. purpureum Schumach.). $\mathrm{m} / z$ 382, campesterol ester series; $\mathrm{m} / z$ 394, stigmasterol ester series; $\mathrm{m} / z$ 396, sitosterol ester series.

generally show fragments arising from the sterol moiety by electron impact MS and rarely give detectable molecular ions. ${ }^{37,38}$ By monitoring the ions corresponding to the different sterol moieties, it was possible to identify series of campesterol, stigmasterol, and sitosterol esters. Figure 6 shows the distribution of the esterified sterols by monitoring the characteristic fragments for the different sterol moieties in their mass spectra, $m / z 382$ for campesterol esters, $m / z 394$ for stigmasterol esters, and $m / z 396$ for sitosterol esters. All of the esterified sterol ester series showed two major peaks for the esterification with $\mathrm{C}_{16}$ and $\mathrm{C}_{18}$ fatty acids, including the unsaturated oleic and linoleic acids, the most predominant sterol ester being sitosterol linoleate 
(XVII). Sterol glycosides were also identified in elephant grass in important amounts $(121 \mathrm{mg} / \mathrm{kg}$ in the cortex and $435 \mathrm{mg} / \mathrm{kg}$ in the pith). Sitosteryl $\beta$-D-glucopyranoside (XVIII) was the most predominant with lower amounts of campesteryl and stigmasteryl $\beta$-D-glucopyranosides. The identification of sterol glycosides was accomplished (after BSTFA derivatization of the lipid extract) by comparison with the mass spectra and relative retention times of authentic standards. ${ }^{39}$

Steroid ketones were identified in relatively high amounts among the lipophilic extractives of elephant grass, being more abundant in the pith $(381 \mathrm{mg} / \mathrm{kg})$ than in the cortex $(89 \mathrm{mg} / \mathrm{kg})$, as also occurred in the related species $M . \times$ giganteus. $^{7}$ The main steroid ketones identified were ergost-4-en-3-one (XIX, $\mathrm{R}=\mathrm{H}$ ), stigmast-4-en-3-one (XIX, $\mathrm{R}=\mathrm{CH}_{3}$ ), ergost-4-ene-3,6-dione ( $\mathbf{X X}$, $\mathrm{R}=\mathrm{H})$, stigmast-4-ene-3,6-dione $\left(\mathbf{X X}, \mathrm{R}=\mathrm{CH}_{3}\right)$, ergostane-3,6dione (XXI, $\mathrm{R}=\mathrm{H})$, stigmastane-3,6-dione (XXI, $\left.\mathrm{R}=\mathrm{CH}_{3}\right)$, stigmasta-4,22-dien-3-one (XXII), stigmasta-3,5-dien-7-one (XXIII), stigmasta-4,22-diene-3,6-dione (XXIV), and stigmast22-ene-3,6-dione (XXV). Finally, several steroid hydrocarbons, such as ergosta-3,5-diene, stigmasta-3,5,7-triene, and stigmasta-3,5diene (XXVI), were also found in minor amounts among the elephant grass extractives, being more abundant in the pith $(23 \mathrm{mg} / \mathrm{kg})$ than in the cortex $(10 \mathrm{mg} / \mathrm{kg})$.

Lignans. Finally, two lignans, namely matairesinol and syringaresinol (Figure 7), could be identified among the<smiles>COc1cc(C[C@H]2COC(=O)[C@@H]2Cc2ccc(O)c(OC)c2)ccc1O</smiles>

matairesinol<smiles>COc1cc([C@H]2OC[C@@H]3[C@H]2CO[C@H]3c2cc(OC)c(O)c(OC)c2)cc(OC)c1O</smiles>

syringaresinol
Figure 7. Structures of the lignans matairesinol and syringaresinol identified in the extracts of elephant grass (P. purpureum Schumach.).

lipophilic extractives of elephant grass. Interestingly, these lignans could be observed only in the cortex, although in low amounts $(9 \mathrm{mg} / \mathrm{kg})$, and were completely absent in the pith. Lignans have been described as powerful antioxidants with metal-chelating properties and therefore have been attributed a protective effect against fungal attack. ${ }^{40}$

In conclusion, this study provides for the first time a comprehensive and detailed chemical characterization of the lipophilic extractives in elephant grass, which is highly valuable information for improving the industrial uses of this interesting fast-growing crop.

\section{AUTHOR INFORMATION}

\section{Corresponding Author}

*Phone: +34-95-4624711. Fax: +34-95-4624002. E-mail: delrio@irnase.csic.es.

\section{Funding}

This study has been funded by the Spanish project AGL201125379, the CSIC project 201040E075, and the EU project LIGNODECO (KBBE-244362). P.P. thanks the Spanish Ministry of Science and Innovation for a FPI fellowship.

\section{Notes}

The authors declare no competing financial interest.

\section{ACKNOWLEDGMENTS}

We thank Prof. Jorge L. Colodette and Prof. Jose L. Gomide (University of Viçosa, Brazil) for providing the elephant grass.

\section{REFERENCES}

(1) Woodard, K. R.; Prine, G. M. Dry matter accumulation of elephant grass, energy cane and elephant millet in a subtropical climate. Crop Sci. 1993, 33, 818-824.

(2) Somerville, C.; Youngs, H.; Taylor, C.; Davis, S. C.; Long, S. P. Feedstocks for lignocellulosic biofuels. Science 2010, 329, 790-792.

(3) Madakadze, I. C.; Masamvu, T. M.; Radiotis, T.; Li, J.; Smith, D. L. Evaluation of pulp and paper making characteristics of elephant grass (Pennisetum purpureum Schum) and switchgrass (Panicum virgatum L.). Afr. J. Environ. Sci. Technol. 2010, 4, 465-467.

(4) Reddy, K. O.; Maheswari, C. M.; Reddy, D. J. P.; Rajulu, A. V. Thermal properties of Napier grass fibers. Mater. Lett. 2009, 63, 23902392.

(5) Reddy, K. O.; Maheswari, C. U.; Shukla, M.; Rajulu, A. V. Chemical composition and structural characterization of Napier grass fibers. Mater. Lett. 2012, 67, 35-38.

(6) del Río, J. C.; Prinsen, P.; Rencoret, J.; Nieto, L.; JiménezBarbero, J.; Ralph, J.; Martínez, A. T.; Gutiérrez, A. Structural characterization of the lignin in the cortex and pith of elephant grass (Pennisetum purpureum) stems. J. Agric. Food Chem. 2012, 60, 36193634.

(7) Villaverde, J. J.; Domingues, R. M. A.; Freire, C. S. R.; Silvestre, A. J. D.; Pascoal Neto, C.; Ligero, P.; Vega, A. Miscanthus $\times$ giganteus extractives: a source of valuable phenolic compounds and sterols. $J$. Agric. Food Chem. 2009, 57, 3626-3631.

(8) Coelho, D.; Marques, G.; Gutiérrez, A.; Silvestre, A. R. D.; del Río, J. C. Chemical characterization of the lipophilic fraction of Giant reed (Arundo donax) fibres used for pulp and paper manufacturing. Ind. Crops Prod. 2007, 26, 229-236.

(9) Back, E. L.; Allen, L. H. Pitch Control, Wood Resin and Deresination; TAPPI Press: Atlanta, GA, 2000.

(10) del Río, J. C.; Gutiérrez, A.; González-Vila, F. J.; Martín, F.; Romero, J. Characterization of organic deposits produced in the Kraft pulping of Eucalyptus globulus wood. J. Chromatogr., A 1998, 823, 457465

(11) del Río, J. C.; Romero, J.; Gutiérrez, A. Analysis of pitch deposits produced in kraft pulp mills using totally chlorine free bleaching sequences. J. Chromatogr., A 2000, 874, 235-245.

(12) Gutiérrez, A.; del Río, J. C. Chemical characterization of pitch deposits produced in the manufacturing of high-quality paper pulps from hemp fibers. Bioresour. Technol. 2005, 96, 1445-1450.

(13) Silvestre, A. J. D.; Pereira, C. C. L.; Neto, C. P.; Evtuguin, D. V.; Duarte, A. C.; Cavaleiro, J. A. S.; Furtado, F. P. Chemical composition of pitch deposits from ECF Eucalyptus globulus bleached kraft pulp mill: its relationship with wood extractives and additives in process streams. Appita J. 1999, 52, 375-382.

(14) Marques, G.; del Río, J. C.; Gutiérrez, A. Lipophilic extractives from several nonwoody lignocellulosic crops (flax, hemp, sisal, abaca) and their fate during alkaline pulping and TCF/ECF bleaching. Bioresour. Technol. 2010, 101, 260-267.

(15) Gutiérrez, A.; del Río, J. C.; González-Vila, F. J.; Martín, F. Analysis of lipophilic extractives from wood and pitch deposits by solid-phase extraction and gas chromatography. J. Chromatogr., A 1998, 823, 449-455.

(16) Gutiérrez, A.; del Río, J. C. Lipids from flax fibers and their fate in alkaline pulping. J. Agric. Food Chem. 2003, 51, 4965-4971.

(17) Gutiérrez, A.; del Río, J. C. Lipids from flax fibers and their fate in alkaline pulping (addition/correction). J. Agric. Food Chem. 2003, 51, 6911-6914.

(18) Gutiérrez, A.; Rodríguez, I. M.; del Río, J. C. Chemical characterization of lignin and lipid fractions in industrial hemp bast 
fibers used for manufacturing high-quality paper pulps. J. Agric. Food Chem. 2006, 54, 2138-2144.

(19) Gutiérrez, A.; Rodríguez, I. M.; del Río, J. C. Chemical characterization of lignin and lipid fractions in kenaf bast fibers used for manufacturing high-quality papers. J. Agric. Food Chem. 2004, 52, 4764-4773.

(20) Gutiérrez, A.; Rodríguez, M. I.; del Río, J. C. Chemical composition of lipophilic extractives from sisal (Agave sisalana) fibers. Ind. Crops Prod. 2008, 28, 81-87.

(21) del Río, J. C.; Gutiérrez, A. Chemical composition of abaca (Musa textilis) leaf fibers used for manufacturing of high quality paper pulps. J. Agric. Food Chem. 2006, 54, 4600-4610.

(22) del Río, J. C.; Marques, G.; Rodríguez, I. M.; Gutiérrez, A. Chemical composition of lipophilic extractives from jute (Corchorus capsularis) fibers used for manufacturing of high-quality paper pulps. Ind. Crops Prod. 2009, 30, 241-249.

(23) del Río, J. C.; Rodríguez, M. J.; Gutiérrez, A. Identification of intact long-chain $p$-hydroxycinnamate esters in leaf fibers of abaca (Musa textilis) using gas chromatography/mass spectrometry. Rapid Commun. Mass Spectrom. 2004, 18, 2691-2696.

(24) Rencoret, J.; Gutiérrez, A.; del Río, J. C. Lipid and lignin composition of woods from different eucalypt species. Holzforschung 2007, 61, 165-174.

(25) Kolattukudy, P. E.; Espelié, K. E. Chemistry, biochemistry, and function of suberin and associated waxes. In Natural Products of Woody Plants; Rowe, J. W., Ed.; Springer-Verlag: Berlin, Germany, 1989; Vol. 1, pp 304-367.

(26) Baldé, A. M.; Claeys, M.; Pieters, L. A.; Wray, V.; Vlietinck, A. J. Ferulic acid esters from stem bark of Pavetta owariensis. Phytochemistry 1991, 30, 1024-1026.

(27) Marques, G.; Gutiérrez, A.; del Río, J. C. Chemical characterization of lignin and lipophilic fractions from leaf fibers of curaua (Ananas erectifolius). J. Agric. Food Chem. 2007, 55, 1327-1336.

(28) Marques, G.; Rencoret, J.; Gutiérrez, A.; del Río, J. C. Evaluation of the chemical composition of different non-woody plant fibers used for pulp and paper manufacturing. Open Agric. J. 2010, 4, 93-101.

(29) Moldovan, Z.; Jover, E.; Bayona, J. M. Systematic characterisation of long-chain aliphatic esters of wool wax by gas chromatography-electron impact ionisation mass spectrometry. $J$. Chromatogr., A 2002, 952, 193-204.

(30) Sharkey, A. G., Jr.; Shultz, J. L.; Friedel, R. A. Mass spectra of esters. Formation of rearrangement ions. Anal. Chem. 1959, 31, 8794.

(31) Evans, D.; Knights, B. A.; Math, V. B.; Ritchie, A. L. $\beta$-Diketones in Rhododendron waxes. Phytochemistry 1975, 14, 2447-2451.

(32) Bianchi, A.; Bianchi, G. Surface lipid composition of $\mathrm{C}_{3}$ and $\mathrm{C}_{4}$ plants. Biochem. Syst. Ecol. 1990, 18, 533-537.

(33) Bianchi, G.; Figini, M. L. Epicuticular waxes of glaucous and nonglaucous durum wheat lines. J. Agric. Food Chem. 1986, 34, 429433.

(34) Tulloch, A. P.; Hoffman, L. L. Epicuticular waxes of Secale cereale and Triticale hexaploide leaves. Phytochemistry 1974, 13, 25352540.

(35) Tulloch, A. P.; Hoffman, L. L. Epicuticular wax of Apropyron intermedium. Phytochemistry 1976, 15, 1145-1151.

(36) Tulloch, A. P. Carbon-13 NMR spectra of $\beta$-diketones from wax of the gramineae. Phytochemistry 1985, 24, 131-137.

(37) Lusby, W. R.; Thompson, M. J.; Kochansky, J. Analysis of sterol esters by capillary gas chromatography electron impact and chemical ionization-mass spectrometry. Lipids 1984, 19, 888-901.

(38) Evershed, R. P.; Prescott, M. C.; Spooner, N.; Goad, L. J. Negative ion ammonia chemical ionization and electron impact ionization mass spectrometric analysis of steryl fatty acyl esters. Steroids 1989, 53, 285-309.

(39) Gutiérrez, A.; del Río, J. C. Gas chromatography/mass spectrometry demonstration of steryl glycosides in eucalypt wood, kraft pulp and process liquids. Rapid Commun. Mass Spectrom. 2001, $15,2515-2520$.
(40) Donoso-Fierro, C.; Becerra, J.; Bustos-Concha, E; Silva, M. Chelating and antioxidant activity of lignans from Chilean woods (Cupressaceae). Holzforschung 2009, 63, 559-563. 